\title{
MYT1L wt Allele
}

National Cancer Institute

\section{Source}

National Cancer Institute. MYT 1L wt Allele. NCI Thesaurus. Code C82898.

Human MYT 1 L wild-type allele is located in the vicinity of 2 p25.3 and is approximately 543

$\mathrm{kb}$ in length. This allele, which encodes myelin transcription factor 1-like protein, plays a role in both neuronal development and transcription. Genetic copy number variation is associated with schizophrenia. 